\title{
Highlights of the ACRL Second National Conference
}

56 contributed paper sessions on such topics as:

information services and bibliographic instruction; special collections and facilities;

performance evaluation and governance;

networking, cooperation, and technology;

standards and collection development;

administration and funding;

the role of the library and the librarian in academic institutions;

planning and bibliographic control.

5 theme speakers addressing our "Options for the 80s":

Thomas Patrick Melady, assistant secretary for postsecondary education, Department of Education;

Robert M. Rosenzweig, vice president for public affairs, Stanford University;

Daniel J. Sullivan, vice president for planning, Carleton College;

Paul A. Lacey, professor of English, Earlham College;

Beverly P. Lynch, university librarian, University of Illinois, Chicago Circle.

Panel discussion-"Options for the 80s":

Moderator: David C. Weber, ACRL president, director of libraries, Stanford University.

Panelists: Sherrie S. Bergman, chair, ACRL College Libraries Section;

Marcia J. Myers, chair, ACRL Community and Junior College Libraries Section;

Joan I. Gotwals, chair, ACRL University Libraries Section.

Conference receptions:

exhibits opening reception;

all-conference reception at the Minneapolis Public Library;

all-conference reception at the St. Paul Landmark Center.

Conference banquet:

Minnesota wild rice soup;

Minnesota lake fish.

Banquet entertainment:

1)udley Riggs' Brave New Workshop presents "You Want Help? I Have a Terminal on My Lap) and a Director in My Ear.

173 corporate exhibit displays.

9 ACRL continuing education courses held prior to the conference:

Effective Supervisory Skills;

Working Effectively with Groups;

An Introduction to Maps in Libraries;

Teaching Methods for the Bibliographic Instruction Librarian;

Basic Archives Management for Libraries;

Establishing the College Bibliographic Instruction Program: The Director's Role;

Writing the Journal Article and Getting It Published;

Career Advancement in Academic Librarianship: Techniques for U'pward Mobility;

Management Issues in Automation and Information Technology.

Job placement service.

Visit the richness of the Twin Cities:

Guthrie Theater:

Walker Arts Center;

Minneapolis Institute of the Arts;

Minnesota Orchestra;

St. Paul Chamber Orchestra;

American Swedish Institute;

Sons of Norway Cultural Center;

Minnehaha Falls;

Minnesota Zoological Gardens. 